OPEN ACCESS

Edited by:

L. Joseph Su,

University of Arkansas for Medical

Sciences, United States

Reviewed by:

Robert Fred Clark,

RTI International, United States

Adora Okogbule-Wonodi,

Howard University, United States

*Correspondence:

Abdulkerim Eroglu

aeroglu@ncsu.edu

tThese authors have contributed equally to this work and share first authorship

\footnotetext{
Specialty section:

This article was submitted to Nutrigenomics,

a section of the journal

Frontiers in Nutrition
}

Received: 10 June 2021

Accepted: 20 August 2021

Published: 27 September 2021

Citation:

Cheng J, Balbuena E, Miller B and Eroglu A (2021) The Role of $\beta$-Carotene in Colonic Inflammation and Intestinal Barrier Integrity. Front. Nutr. 8:723480.

doi: $10.3389 /$ fnut.2021.723480

\section{The Role of $\beta$-Carotene in Colonic Inflammation and Intestinal Barrier Integrity}

\author{
Junrui Cheng ${ }^{1 \dagger}$, Emilio Balbuena ${ }^{1,2 \dagger}$, Baxter Miller ${ }^{1}$ and Abdulkerim Eroglu ${ }^{1,2 *}$ \\ ${ }^{1}$ Plants for Human Health Institute, North Carolina State University, Kannapolis, NC, United States, ${ }^{2}$ Department of \\ Molecular and Structural Biochemistry, College of Agriculture and Life Sciences, North Carolina State University, Raleigh, NC, \\ United States
}

Background: Carotenoids are naturally occurring pigments accounting for the brilliant colors of fruits and vegetables. They may display antioxidant and anti-inflammatory properties in humans besides being precursors to vitamin A. There is a gap of knowledge in examining their role within colonic epithelial cells. We proposed to address this research gap by examining the effects of a major dietary carotenoid, $\beta$-carotene, in the in vitro epithelial cell model.

Methods: We examined the function of $\beta$-carotene in the lipopolysaccharide (LPS)/tolllike receptor 4 (TLR4) signaling pathway. We conducted western blotting assays to evaluate expressions of TLR4 and its co-receptor, CD14. We also examined NF-кB p65 subunit protein levels in the model system. Furthermore, we studied the impact of $\beta$ carotene on the tight junction proteins, claudin-1, and occludin. We further carried out immunocytochemistry experiments to detect and visualize claudin-1 expression.

Results: $\beta$-Carotene reduced LPS-induced intestinal inflammation in colonic epithelial cells. $\beta$-Carotene also promoted the levels of tight junction proteins, which might lead to enhanced barrier function.

Conclusions: $\beta$-Carotene could play a role in modulating the LPS-induced TLR4 signaling pathway and in enhancing tight junction proteins. The findings will shed light on the role of $\beta$-carotene in colonic inflammation and also potentially in metabolic disorders since higher levels of LPS might induce features of metabolic diseases.

Keywords: $\beta$-carotene, colonic inflammation, colonic epithelial cells, tight junctions, vitamin A

\section{INTRODUCTION}

Carotenoids are naturally occurring pigments responsible for the brilliant colors of fruits, vegetables, and microalgae $(1,2)$. Along with the carotenoids containing 30, 45, or 50 carbon atoms that are mainly observed in archaea and bacteria via biosynthesis $(3,4)$, the most abundant carotenoids in nature are $\mathrm{C} 40$ carotenoids $(4,5)$, which are formed with the cyclization, isomerization, and oxidation of eight $\mathrm{C} 5$ isoprenoid units $(4,6,7)$. As one of the C40 carotenoids, $\beta$-carotene is the most prevalent carotenoid in North American diets and detected in human serum $(8,9)$; thus it is widely studied, especially for its potential beneficial effects in humans. Chemically, $\beta$-carotene is a hydrocarbon carotenoid, composed of the long chain of alternating double bonds (polyene chain) and $\beta$-ionone rings at both terminal groups (10). From the biological point of 
view, $\beta$-carotene is one of the major dietary provitamin $\mathrm{A}$ carotenoids, meaning that it can be cleaved by beta-carotene$15,15^{\prime}$-oxygenase 1 (BCO1) at the central double bond of the polyene chain to yield two molecules of all-trans retinal, which can be further oxidized to all-trans retinoic acid (ATRA), the main biologically active form of vitamin A, or reduced to alltrans retinol (11). In addition to central (symmetrical) cleavage, eccentric cleavage can take place asymmetrically resulting in the formation of $\beta$-apo-10'-carotenal and $\beta$-ionone (10). Other apocarotenoids, such as $\beta$-apo-8'-carotenal, $\beta$-apo-12'-carotenal, and $\beta$-apo-14'-carotenal, can also be formed enzymatically and non-enzymatically (10). Physiologically within humans, $\beta$ carotene is released from the food matrix and incorporated into mixed micelles in order to be absorbed within intestinal cells. Moreover, this cellular uptake occurs through a mechanism of passive diffusion or facilitated transport via scavenger receptor class B type 1 (SR-B1) (12). Finally, $\beta$-carotene is incorporated into chylomicrons for secretion and transport into the lymph (13).

Besides being a precursor to vitamin $A, \beta$-carotene can exert antioxidant and anti-inflammatory properties in humans. The anti-inflammatory effects of $\beta$-carotene have been demonstrated in multiple systems. Schultz et al. showed a reverse correlation between plasma $\beta$-carotene and C-reactive protein (CRP), a systemic inflammatory biomarker (14). Additionally, by administrating $\beta$-carotene- ${ }^{14} \mathrm{C}$ intraduodenally, Crain et al. reported that appreciable amounts of $\beta$-carotene was converted to ATRA in the rat intestinal mucosa (15), highlighting the possibility that both $\beta$-carotene and ATRA could be bioactive compounds that affected the homeostasis of the gastrointestinal (GI) system. Another study showed that subjects containing lower levels of $\beta$-carotene had increased levels of CRP and interleukin-6 (IL-6) (16), an inflammatory cytokine that contributes to the pathogenesis of various GI diseases $(17,18)$. Furthermore, multiple mechanistic studies were conducted to explore the signaling pathways involved in the anti-inflammatory activity of $\beta$-carotene. Among those, $\beta$-carotene was noted for inhibition of NF- $\kappa \mathrm{B}$ translocation by blocking the activation of the NF- $\kappa$ B p65 subunit (19), leading to decreased transcription of pro-inflammatory cytokine genes such as interelukin-1 $\beta$ (IL-1 $\beta$ ), IL-6, and tumor necrosis factor alpha (TNF- $\alpha$ ) (20). Regarding a causative aspect of inflammation, lipopolysaccharide (LPS) is a surface molecule derived from the outer membrane of almost all gram-negative bacteria (21). Accumulating evidence has revealed that LPS can induce pathogen recognition receptors (PRRs), such as TLR4, which subsequently activates NF- $\kappa B$, leading to the translocation of NF- $\kappa \mathrm{B}$ from the cytoplasm to the nucleus (22). The mammalian NF- $\kappa \mathrm{B}$ has various subunits including p65, p50, c-Rel, RelB that may form different types of heteroor homodimers (23), but the p50/p65 heterodimer is the most

\footnotetext{
Abbreviations: LPS, lipopolysaccharide; TLR4, toll-like receptor 4; ICC, immunocytochemistry; BCO1, beta-carotene-15,15' -oxygenase 1; ATRA, all-trans retinoic acid; $\mathrm{BCO} 2$, beta-carotene- $9,10^{\prime}$-oxygenase 2 ; SR-B1, scavenger receptor class B type 1; CRP, C-reactive protein; GI, gastrointestinal; PRR, pathogen recognition receptor; IFN- $\gamma$, Interferon- $\gamma$; IL-6, Interleukin-6; IL-1 $\beta$, Interleukin$1 \beta$; TNF- $\alpha$, Tumor Necrosis Factor- $\alpha$; BCA, Bicinchoninic Acid; DAPI, 4',6diamidino-2-phenylindole; WCL, whole cell lysate.
}

common (24). NF-кB contributes to various pro-inflammatory activities due to its ability to transcriptionally activating proinflammatory cytokines including IL-6, IL-1 $\beta$, and TNF- $\alpha$ (25).

Tight junctions are multiprotein cell-cell adhesion complexes whose functions are regulated by various tight junction proteins, which together help maintain the integrity of the intestinal barrier (26). Tight junction proteins including claudin-1, claudin-3, and claudin-15 significantly decreased, leading to increased intestinal permeability in a high-fat diet-induced obese mice model (27). A leaky gut allows the release of detrimental exterior molecules from the GI tract to the host, facilitating the progression of systemic inflammation (28). Therefore, it is important to develop an effective method to mitigate LPSinduced colonic inflammation and the impairment of gut integrity. The objective of this study was to investigate whether $\beta$-carotene could be a bioactive compound in modulating LPSinduced inflammation and tight junction protein changes in colonic epithelial cells.

\section{MATERIALS AND METHODS}

\section{Chemicals and Reagents}

All-trans retinoic acid (Catalog \#R2625) and $\beta$-carotene (Catalog \#C9750) were purchased from Millipore Sigma (Burlington, MA, USA). Fetal Bovine Serum (FBS), Penicillin-Streptomycin (Pen-Strep, 100X), McCoy's 5A medium, and LPS from E. coli serotype EH100 were purchased from Thermo Fisher Scientific (Waltham, MA, USA). Interferon- $\gamma$ (IFN- $\gamma$ ) was purchased from R\&D Systems (Minneapolis, MN, USA). PureLink RNA extraction kit was obtained from Thermo Fisher Scientific, and Novo cDNA kit was purchased from BioVision Inc. (Milpitas, CA, USA). PowerUp SYBR Green Master Mix was purchased from Thermo Fisher Scientific. Nuclear extract kit and ProStain Protein Quantification Kit were obtained from Active Motif (Carlsbad, CA, USA). For western blot, the primary antibodies including TLR4 (category number sc-293072), NF-кB p65 (sc-8008), C-reactive protein (CRP, sc-69770), GAPDH (sc-47724) and $\beta$-actin (sc-47778) were mouse monoclonal antibodies and were obtained from Santa Cruz Biotechnology (Dallas, TX, USA). The primary antibodies including claudin-1 (13255), occludin (91131), and CD14 (56082) were rabbit monoclonal antibodies, and were purchased from Cell Signaling Technology (Danvers, MA, USA). The anti-mouse secondary HRP-conjugated antibodies were purchased from Santa Cruz Biotechnology, whereas the anti-rabbit HRP-conjugated antibodies were purchased from Cell Signaling Technology. Precision Plus Protein ${ }^{\mathrm{TM}}$ Standards were purchased from Bio-Rad Laboratories (Hercules, CA, USA). IL-6 (RAB0306) and IL-1 $\beta$ (RAB0273) ELISA kits were purchased from Millipore Sigma. TNF- $\alpha$ ELISA kit (DTA00D) was purchased from R\&D Systems. For immunocytochemistry (ICC), claudin-1 (D-4) was obtained from Santa Cruz Biotechnology, and the goat anti-mouse secondary antibody Alexa fluor 488 conjugates (A-11029) was purchased from Thermo Fisher Scientific. ImmunoCruz ABC Kit (sc-516216) was purchased from Santa Cruz Biotechnology, and Fluoromount-G Mounting Medium (00-4959-52) was purchased from Thermo Fisher Scientific. 


\section{Cell Culture and Treatment}

HT-29 cells (human colorectal adenocarcinoma cell line) were purchased from the American Type Culture Collection (ATCC, HTB-38) (Manassas, VA, USA). HT-29 cells were used between passages 5-25 in this study. These cells were cultured in McCoy's $5 \mathrm{~A}$ medium containing $10 \%$ FBS and $1 \mathrm{X}$ Pen-Strep, and were housed in a humidified atmosphere of $95 \%$ air and $5 \% \mathrm{CO}_{2}$ at $37^{\circ} \mathrm{C}$. Cells were propagated according to the protocol published previously (29). Briefly, for individual assays, cells were seeded at a density of $2.5 \times 10^{5}$ per well in $2 \mathrm{~mL}$ media overnight, followed by IFN- $\gamma$ pre-treatment at $50 \mathrm{ng} / \mathrm{mL}$ for $12 \mathrm{~h}$, and stimulated with $1 \mu \mathrm{g} / \mathrm{mL}$ LPS with or without $\beta$-carotene or ATRA treatments at different dosages $(1,10,100 \mathrm{nM}, 1$, and $10 \mu \mathrm{M})$.

Colonic epithelial cells and supernatants were harvested after $15 \mathrm{~h}$ and stored at $-20^{\circ} \mathrm{C}$. The doses and time points of IFN- $\gamma$ and LPS treatment were selected based on the previous report (30) and the results of the preliminary study (Supplementary Figure 1).

\section{RNA Isolation}

The extraction of mRNA was performed by employing the PureLink RNA Mini Kit according to the manufacturer's instructions and was previously reported (29). In brief, lysis buffer with 1\% 2-mercaptoethanol was used to lyse the cells, and the entire content was transferred to the RNase-free microcentrifuge tubes and washed with $70 \%$ ethanol. After centrifugation at $2,000 \times g$ for $2 \mathrm{~min}$, the supernatant was transferred to the cartridges for further filtration. Then, the cartridges were washed with two different wash buffers at separate times, and $50 \mu \mathrm{L}$ nuclease-free water was added to the center of the cartridges to extract the total RNA. SpectraMax QuickDrop Micro-Volume Spectrophotometer (Molecular Devices, LLC - San Jose, CA, USA) was utilized to examine RNA quality and quantity.

\section{cDNA Synthesis and Quantitative PCR (qPCR)}

cDNA was synthesized from 500 ng RNA samples using the Novo cDNA kit and Biometra TAdvanced 96G Thermal Cycler System (Analytik Jena - Jena, Germany) as reported previously (29). The program conditions were $25^{\circ} \mathrm{C}$ for $10 \mathrm{~min}, 42^{\circ} \mathrm{C}$ for $50 \mathrm{~min}$, and $85^{\circ} \mathrm{C}$ for $5 \mathrm{~min}$. The detection of mRNA of each sample was carried out by mixing $10 \mu \mathrm{L} 2 \mathrm{X}$ PowerUp SYBR Green Master Mix, $2 \mu \mathrm{L}$ of $10 \mu \mathrm{M}$ primer mix that includes forward and reverse primers, $3 \mu \mathrm{L}$ DNase-free water, and $5 \mu \mathrm{L}$ standardized cDNA. Cycling conditions were $50^{\circ} \mathrm{C}$ for $2 \mathrm{~min}$ and $95^{\circ} \mathrm{C}$ for $10 \mathrm{~min}$; followed by 40 cycles at $95^{\circ} \mathrm{C}$ for $15 \mathrm{~s}, 60^{\circ} \mathrm{C}$ for $15 \mathrm{~s}$; then $95^{\circ} \mathrm{C}$ for $15 \mathrm{~s}, 60^{\circ} \mathrm{C}$ for $1 \mathrm{~min}$ and $95^{\circ} \mathrm{C}$ for $15 \mathrm{~s}$. Primers were designed using the Primer-BLAST tool at NCBI. Primer sequences were list in Supplementary Table 1.

\section{Whole Cell/Nuclear Protein Extraction and Western Blot}

Whole cell lysates were extracted by using radioimmunoprecipitation assay (RIPA) buffer containing $1 \%$ protease inhibitors. Protein concentration was determined by the Bicinchoninic Acid (BCA) Method according to manufacturer instructions.

Nuclear protein was extracted by utilizing the Nuclear Extract Kit as instructed by the manufacturer. Briefly, cells were scraped with ice-cold PBS with phosphatase inhibitors and centrifuged at $200 \times g$ at $4^{\circ} \mathrm{C}$. Subsequently, Hypotonic Buffer and Detergent were added to the resuspended cells, followed by centrifugation for $30 \mathrm{~s}$. at $14,000 \times g$ at $4^{\circ} \mathrm{C}$. After removal of the supernatant (cytoplasmic fraction), the nuclear pellets were suspended in Complete Lysis Buffer and incubated for $30 \mathrm{~min}$. on ice. Then, the mixture was centrifuged for $10 \mathrm{~min}$ at $14,000 \times g$, and the supernatant (nuclear fraction) was collected and stored at $-80^{\circ} \mathrm{C}$. Nuclear protein concentration was quantified by using the ProStain Protein Quantification Kit according to the manufacturer's instructions. The fluorescence was measured at $488 \mathrm{~nm}$ (excitation) and $635 \mathrm{~nm}$ (emission).

To examine specific protein expression, both whole cell lysates and nuclear protein were standardized with molecular biology grade water and mixed with a NuPAGE LDS Sample Buffer $(4 \mathrm{x})$ and NuPAGE Reducing Agent (10x). The mixture was then incubated at $70^{\circ} \mathrm{C}$ for $10 \mathrm{~min}$. To detect the tight junction proteins, $40 \mu \mathrm{L}$ protein was loaded to the gel, whereas 15$20 \mu \mathrm{L}$ protein was loaded to detect other proteins by using the electrophoresis. Whole protein extracts of A431 cells (an epidermoid carcinoma cell line) provided by Cell Signaling Technology (Danvers, MA, USA) was used as positive control for the detection of tight junction proteins. Then, proteins were transferred to a nitrocellulose membrane by using the iBlot2 dry transfer system. The membranes were non-specifically blocked with 5\% Bovine Serum Albumin (BSA) for $1 \mathrm{~h}$, followed by primary antibody incubation at $4^{\circ} \mathrm{C}$ overnight. Secondary antibodies were applied to the membranes that were blocked with non-HRP conjugated primary antibodies. Chemiluminescent reagents were added to the membranes to detect the signals. Protein expressions were detected by using a UVP ChemStudio imaging system (Analytik Jena). The target protein bands were at the expected positions within the blots and non-specific bands were not observed; therefore, we are confident that the antibodies' target was displayed as specified by the manufacturer.

\section{Enzyme-Linked Immunosorbent Assay (ELISA)}

Supernatants were collected from cultured cells and stored in $-20^{\circ} \mathrm{C}$. Quantitative measurement of IL-6, IL- $1 \beta$, and TNF$\alpha$ in both supernatants and whole cell lysates (WCL) was conducted according to the manufacturer's instructions of the commercialized human ELISA kits, which were kit-specific to our cytokines of interest. The optical density of each sample was assessed by using the Synergy H1 microplate reader (BioTek, Winooski, VT, USA).

\section{Immunocytochemistry (ICC)}

The intensity and localization of claudin-1 were assessed by immunofluorescent antibody labeling. Briefly, cells on the coverslips were fixed with $4 \%$ paraformaldehyde for $10 \mathrm{~min}$ at room temperature, followed by washing using ice-cold PBS. Then, the cells were non-specifically blocked with 1\% BSA 


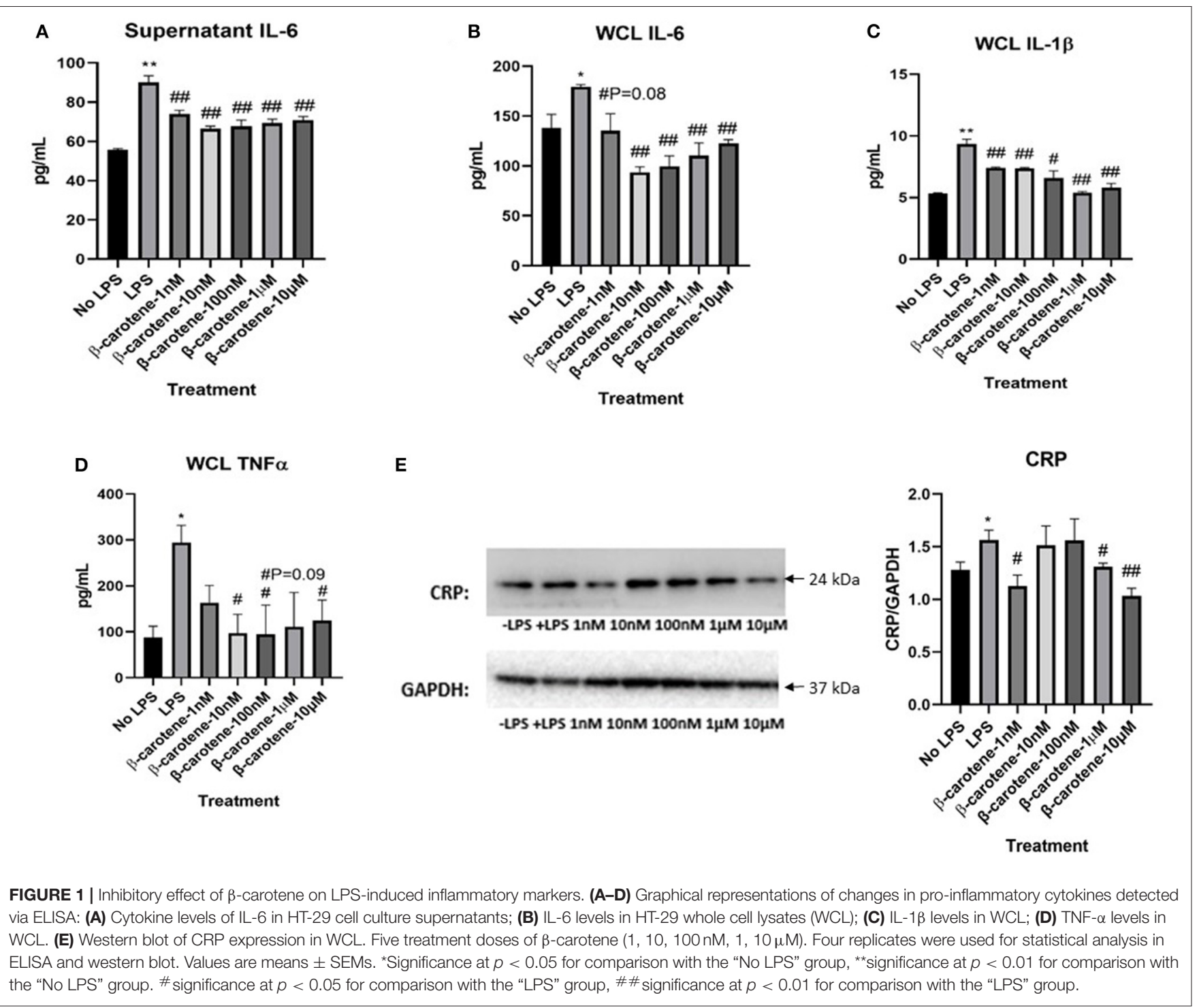

and $22.53 \mathrm{mg} / \mathrm{mL}$ glycine in PBST (PBS + 0.1\% TWEEN 20) for $30 \mathrm{~min}$. After rinsing with PBS for 3 times, the cells were incubated in primary antibody (1:10 diluted in $1 \%$ BSA) overnight, followed by incubation in the secondary antibody Alexa fluor 488 conjugate (1:10 diluted in $1 \%$ BSA) for $1 \mathrm{~h}$ at room temperature in the dark. The cells were then incubated in a reagent mixture from ImmunoCruz $\mathrm{ABC}$ Kit for $15 \mathrm{~min}$ to amplify the signals. Fluoromount-G Mounting Medium with 4',6-diamidino-2-phenylindole (DAPI) was used to mount the coverslips to the slides as well as provide a blue nuclear counter stain. Immunolocalizations of claudin-1 was visualized using a ZEISS LSM710 confocal fluorescence microscope (Carl Zeiss AG, Oberkochen, Germany) equipped with a ZEISS camera.

\section{Statistical Analysis}

Normality of distribution of the total samples was examined by utilizing the D'Agostino-Pearson omnibus normality test. If $p>0.05$, the data were considered as normally distributed.
Equality of variance of data within each group was determined by using an $\mathrm{F}$ test. If $p>0.05$, the data was considered as equal variances. Student's $t$-test was performed to compare the mean of the control group to the mean of the treatment group. A $p<0.05$ was an indication of statistical significance. Each experiment was carried out in quadruplicates to ensure reproducibility.

\section{RESULTS}

\section{$\beta$-Carotene Inhibited LPS-Induced Inflammation}

The levels of pro-inflammatory cytokines (IL-6, IL-1 $\beta$, and TNF- $\alpha$ ) were determined using ELISA procedures in both the cell culture supernatants and whole cell lysates (WCL) in HT29 cells treated with $\beta$-carotene. LPS stimulation significantly increased the levels of IL-6 in both supernatant (Figure 1A) 


\section{A Claudin-1:}

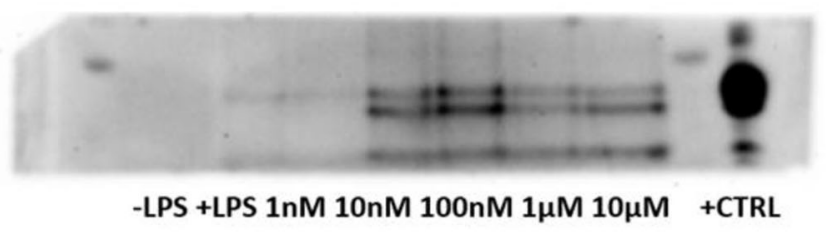

B Occludin:

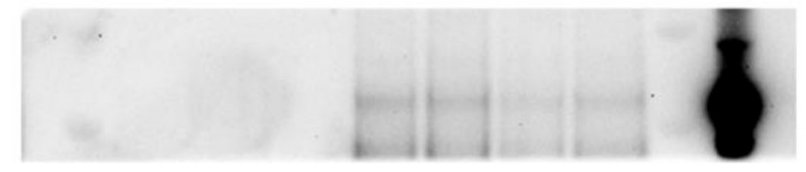

-LPS +LPS 1nM 10nM 100nM 1 $\mu \mathrm{M} 10 \mu \mathrm{M}+\mathrm{CTRL}$

\section{GAPDH:}

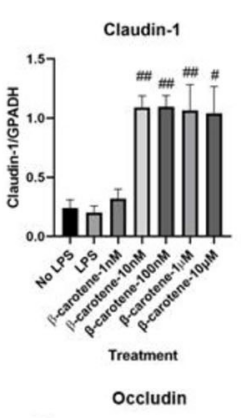

C

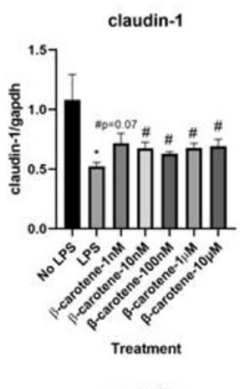

D
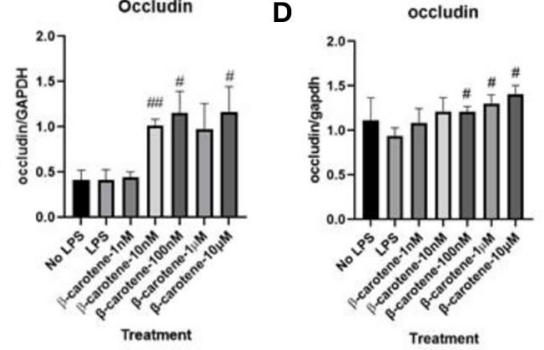

FIGURE 2 | $\beta$-Carotene treatments induce tight junction proteins. (A,B) Western blot membranes with tight junction protein expression of (A) claudin-1 and (B) occludin. Positive control (+CTRL), obtained from A431 cells. (C,D) Fold changes in mRNA levels of (C) claudin-1 and (D) occludin generated from qPCR. Five treatment doses of $\beta$-carotene $(1,10,100 \mathrm{nM}, 1,10 \mu \mathrm{M})$. Four replicates used for statistical analysis of western blot and qPCR. Values are means \pm SEMs. *significance at $p<0.05$ for comparison with the "No LPS" group. \# significance at $p<0.05$ for comparison with the "LPS" group, \#\# significance at $p<0.01$ for comparison with the "LPS" group.

and WCL (Figure 1B) of these cells compared to the cells not treated with LPS ("No LPS") as expected. $\beta$-Carotene treatment subsequently decreased IL-6 levels in all treatment groups $(1 \mathrm{nM}$, $10 \mathrm{nM}, 100 \mathrm{nM}, 1 \mu \mathrm{M}$, and $10 \mu \mathrm{M})$ in the supernatant samples and nearly all treatments in the WCL compared to the LPS stimulated control; even at the $1 \mathrm{nM} \beta$-carotene treatment group, the level of IL- 6 decreased, although the $p$-value was not significant.

Furthermore, LPS stimulation significantly increased IL-1 $\beta$ levels compared to "No LPS" as expected (Figure 1C). $\beta$ Carotene treated WCL showed a significant decrease in IL- $1 \beta$ cytokine levels at all concentrations compared to the LPS control. Supernatant levels of IL-1 $\beta$ were too low to be detected via ELISA. Finally, LPS stimulation significantly increased TNF- $\alpha$ levels compared to "No LPS" (Figure 1D), as seen with the other cytokines. Although supernatant levels of TNF- $\alpha$ were too low to be quantified via ELISA, $\beta$-carotene treated WCL showed a significant decrease in TNF- $\alpha$ cytokine levels at most concentrations in comparison to the LPS control. Additionally, $\beta$-carotene treatment showed a non-significant decreasing trend at $1 \mu \mathrm{M}$. The ELISA results indicated that $\beta$-carotene had an inhibitory effect on the LPS-stimulated release of these pro-inflammatory cytokines. Also, CRP in HT-29 WCL was significantly increased upon LPS stimulation relative to the untreated control, and $\beta$-carotene decreased CRP at 1 and $10 \mu \mathrm{M}$ (Figure 1E). Interestingly, $1 \mathrm{nM} \beta$-carotene was able to significantly decrease CRP expression, but 10 and $100 \mathrm{nM}$ did not reach statistical significance; in this case, this phenomenon may not be dose-dependent.

\section{$\beta$-Carotene Improved Tight Junction Proteins}

We explored the efficacy of $\beta$-carotene treatment in modulating tight junction proteins. Regarding claudin-1, the expected decrease of expression upon LPS stimulation was not significantly shown (Figure 2A). However, the expression of claudin-1 was drastically increased with the medium to high $\beta$-carotene doses of $10,100 \mathrm{nM}, 1$ and $10 \mu \mathrm{M}$. These substantial changes due to $\beta$-carotene treatment at these concentrations were also significant compared to the baseline levels ("No LPS") of claudin1 expression. There was a similar trend with occludin expression (Figure 2B). The positive control, obtained from the epidermoid carcinoma cell line (A431), demonstrated a strong expression of both claudin-1 and occludin in comparison to HT-29 cells indicating that HT-29 cells might have the low endogenous expression of tight junction proteins. We also assessed the mRNA levels of claudin-1 and occludin in the same in vitro model. The LPS only treatment group led to a significant decrease in claudin1 levels, whereas the $\beta$-carotene treatment provided an overall significant increase in claudin- 1 at most concentrations, with the exception for the non-significant increase at $1 \mathrm{nM}$ (Figure 2C). Similar results were observed regarding levels of occludin as LPS treated samples showed a non-significant decrease and $\beta$-carotene treated samples resulted in increased levels, with significant increases at higher doses of $100 \mathrm{nM}, 1$, and $10 \mu \mathrm{M}$ (Figure 2D).

Qualitative analysis of confocal fluorescence microscopy images was obtained to verify the effects of $\beta$-carotene on tight junction protein expression changes in HT-29 cells 
(Figure 3). LPS decreased the expression of claudin-1 as expected, and $\beta$-carotene increased the claudin-1 expression across all concentration groups compared to LPS treatment alone. Furthermore, the intensity at the higher end of our treatment range at concentrations of 1 and $10 \mu \mathrm{M}$ appeared to be stronger than that of the "No LPS" group. These results were correlated with the western blotting results and indicated that $\beta$-carotene could upregulate claudin-1 tight junction levels.

\section{$\beta$-Carotene Metabolism - Its Cellular Uptake and Conversion}

$\beta$-Carotene is a provitamin-A carotenoid, so its metabolite ATRA, the biologically active form of vitamin A, is of particular interest. We first determined its uptake into the colonic epithelial cells via checking SR-B1 levels under our treatment conditions, and there were no observed significant differences of srb1 mRNA levels between "No LPS" and LPS stimulated groups (Supplementary Figure 2A). Likewise, there were no significant changes of srb1 expression across the $\beta$-carotene treated samples compared to the LPS stimulated group. Therefore, SR-B1 was not significantly affected by the presence of LPS or $\beta$-carotene. Furthermore, we examined the expression of BCO1 in our model, and upon LPS stimulation, there was a significant increase in bco1 mRNA (Supplementary Figure 2B). However, $\beta$-carotene did not significantly affect bcol mRNA expression except for a downregulation at the $10 \mu \mathrm{M}$ treatment group, which could indicate that $\beta$-carotene may not significantly hinder the $\mathrm{BCO} 1$ related cleavage under LPS conditions.

\section{ATRA Did Not Alter LPS-Induced Inflammation}

Determining how ATRA modulates tight junction proteins and LPS-induced inflammation was essential to understanding whether the anti-inflammatory nature of $\beta$-carotene was due to ATRA or the parent compound, $\beta$-carotene. As seen previously, ELISA tests showed that LPS stimulation significantly increased the levels of IL-1 $\beta$ in both supernatant (Figure 4A) and WCL (Figure 4B) samples of these cells compared to that of the cells not treated with LPS. However, no sufficient data was shown in this study to justify that ATRA altered LPS-induced inflammation. In this case, ATRA did not significantly decrease IL-1 $\beta$ supernatant levels, except for at $10 \mathrm{nM}$ (Figure 4A).

We also examined how TNF- $\alpha$ proteins were changed in WCL through ATRA treatments. LPS stimulation significantly increased TNF- $\alpha$ levels compared to "No LPS" (Figure 4C). Yet, ATRA had no observed effects on TNF- $\alpha$ WCL levels, except at $1 \mu \mathrm{M}$. Supernatant levels of TNF- $\alpha$ were not detectable via ELISA. Based on these results, ATRA did not inhibit LPS-induced production of cytokines to the extent observed in $\beta$-carotene treated HT-29 cells. Additionally, LPS treatment increased CRP expression levels (Figure 4D), yet treatments of ATRA led to observed no changes, except for the significant decrease at $10 \mu \mathrm{M}$. Based on these collective results, ATRA appeared to have minimal effect on LPS-induced inflammation within HT-29 cells.

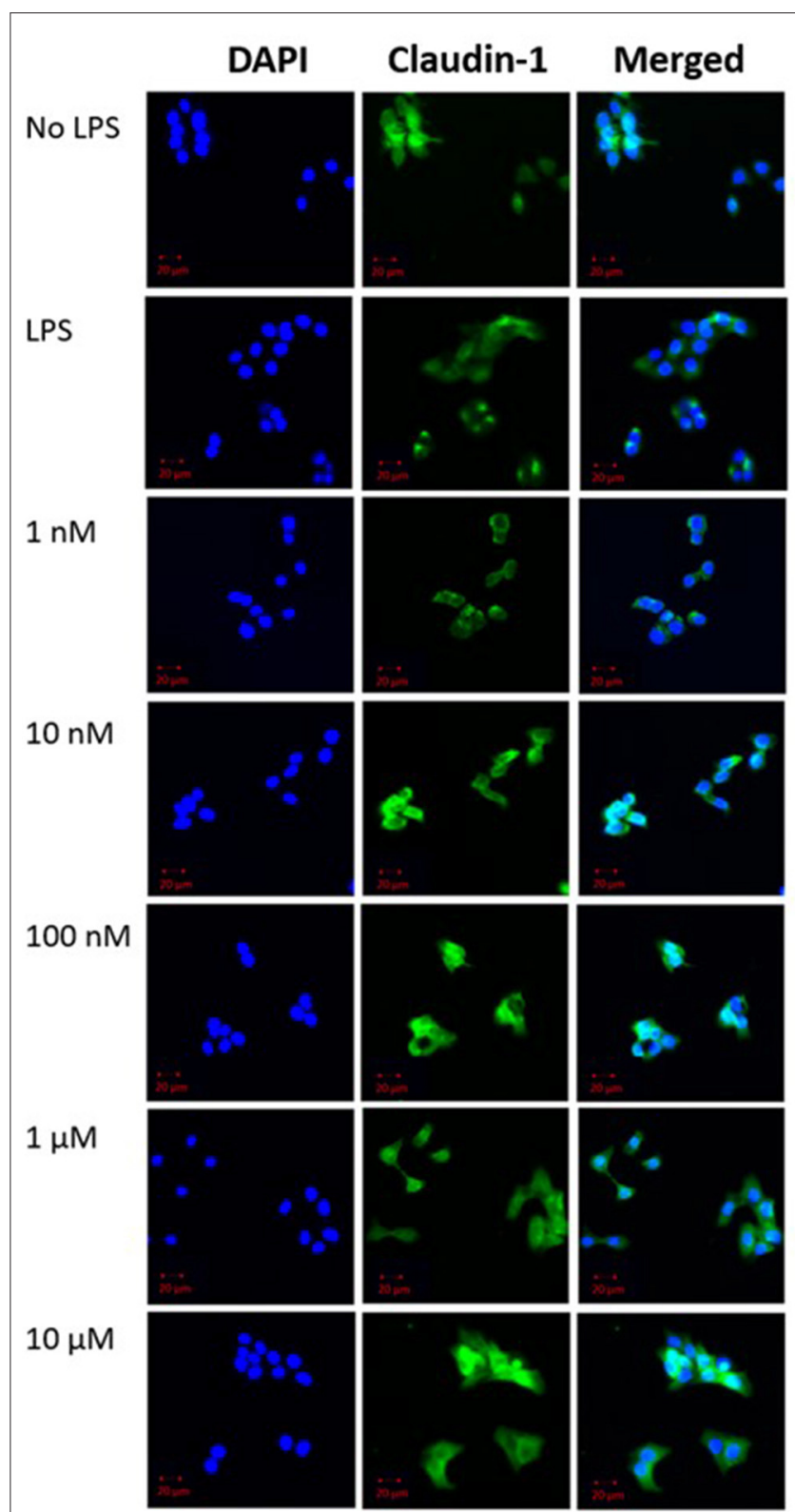

FIGURE 3 | $\beta$-Carotene promotes claudin-1 protein expression. Confocal microscope images of claudin-1 protein expression. (DAPI panel) HT-29 cell nuclei indicated via DAPI staining. (Claudin-1 panel) Protein expression of claudin-1 expression portrayed by fluorescent staining via Alexa Fluor 488. Panels are merged in the final panel for visualization of localization. Five treatment doses of $\beta$-carotene $(1,10,100 \mathrm{nM}, 1,10 \mu \mathrm{M})$. Scale bar of $20 \mu \mathrm{m}$ was included for size comparison.

\section{ATRA Did Not Alter Tight Junction Proteins}

To further define the role of ATRA in LPS induced inflammation in our cell model, more experiments were conducted to assess whether it could modulate the expression of tight junction proteins. Like with the $\beta$-carotene treated HT-29 cells, expressions of claudin-1 and occludin were assessed with ATRA administration. There was no apparent increase 


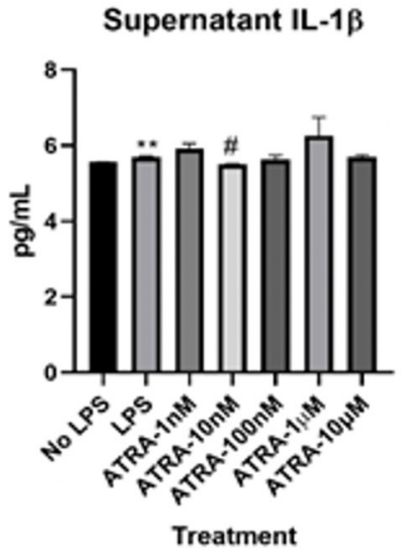

D
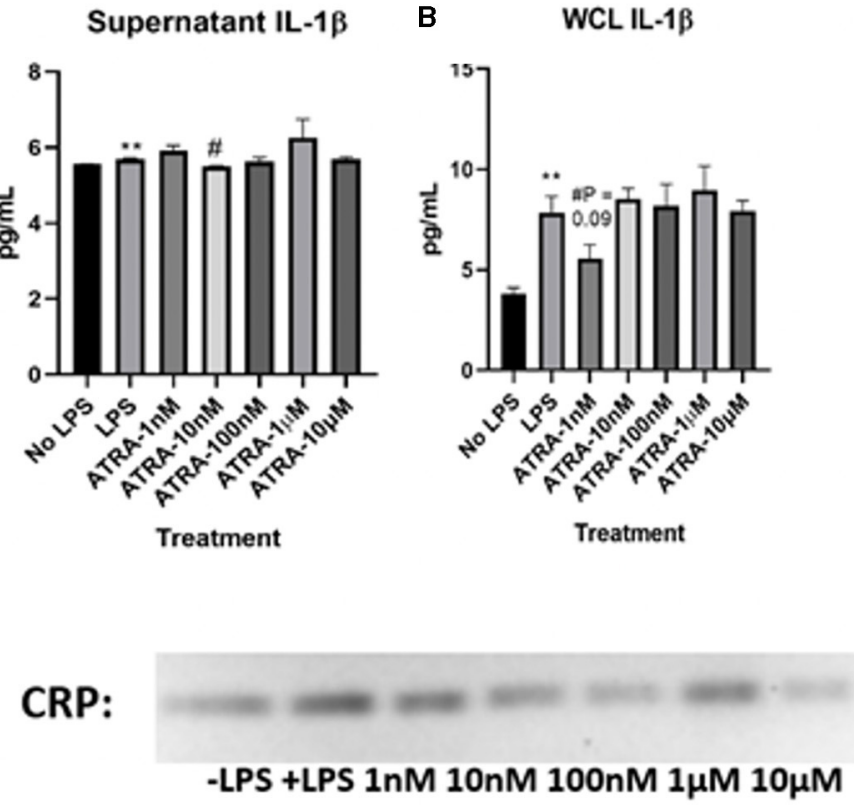

GAPDH:

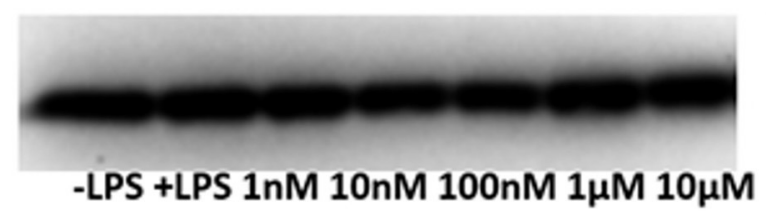

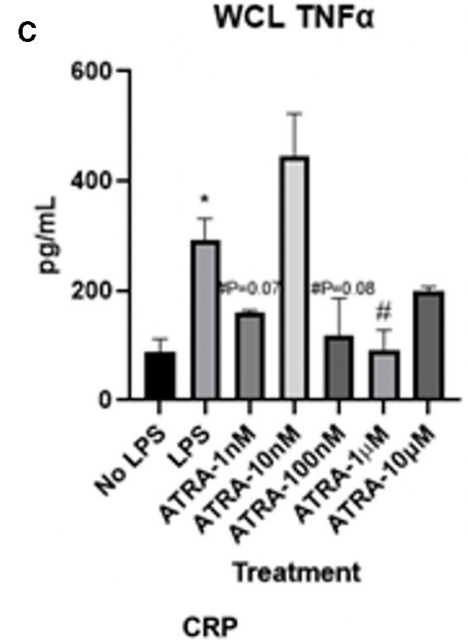

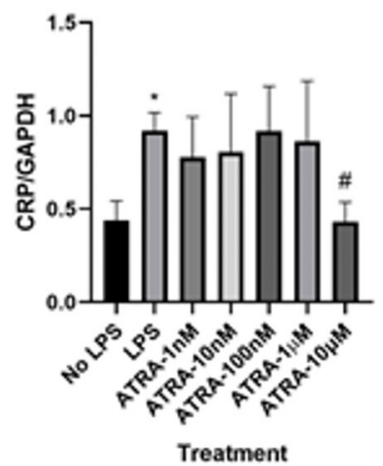

FIGURE 4 | ATRA minimally affects LPS-induced inflammatory markers. (A-C) Graphical representations of fold changes in pro-inflammatory cytokines detected via ELISA: (A) Cytokine levels of IL-1 $\beta$ in HT-29 cell culture supernatants; (B) IL-1 $\beta$ levels in HT-29 whole cell lysates (WCL); (C) TNF- $\alpha$ levels in WCL. (D) Western blot of CRP expression in WCL. Five treatment doses of ATRA (1, 10, $100 \mathrm{nM}, 1,10 \mu \mathrm{M})$. Four replicates were used for statistical analysis in ELISA and western blot. Values are means \pm SEMs. *significance at $p<0.05$ for comparison with the 'No LPS' group, **significance at $p<0.01$ for comparison with the "No LPS" group.

\# significance at $p<0.05$ for comparison with the "LPS" group.

of claudin-1 expression with the treatment of ATRA upon LPS stimulated cells (Figure 5A). Furthermore, the finding of ATRA's minimal effect on claudin-1 was opposite compared to the observations of the $\beta$-carotene treated HT-29 cells, as those indicated an increase in claudin-1 expression upon treatment. Likewise, ATRA notably had no effect on occludin across all treatment conditions and failed to improve expression (Supplementary Figure 3A).

Consistently, our qPCR results showed non-significant trends of increasing claudin-1 mRNA levels LPS stimulation and ATRA treatments (Figure 5B). An increase of claudin1 expression was observed at the $10 \mu \mathrm{M}$ level of ATRA treatment, but not significant in measure. Results from all other treatment arms indicate that ATRA did not affect mRNA for claudin-1 expression. Additionally, insufficient data was found regarding occludin mRNA levels after ATRA treatment (Supplementary Figure 3B). Overall, ATRA administration did not significantly influence tight junction protein modulation.

\section{$\beta$-Carotene Inhibited the TLR4/NF- $k B$ Pathway}

It is known that elevated levels of LPS promote a proinflammatory cascade through activation of toll-like receptor 4 (TLR4) (22). We showed that stimulation of LPS increased TLR4 expression within HT-29 WCL (Figure 6A). $\beta$-Carotene was subsequently beneficial toward inhibiting this LPS-induced TLR4 activation at higher treatment dosages of 1 and $10 \mu \mathrm{M}$. Previous reports showed beneficial effects of CD14 against inflammatory bowel disease by mitigating inflammation and enhancing intestinal barrier function $(31,32)$. In the current study, $\beta$ carotene concentrations promoted CD14 membrane protein levels at all tested doses, except $1 \mathrm{nM}$, and such modulation may correlate to regulation of the tight junction claudin-1 and occludin proteins (Figure 6B). As this inflammatory status of HT-29 cells could also be attributed to NF- $\kappa$ B signaling, we investigated the modulation of $\beta$-carotene on the NF- $\kappa$ B p65 subunit. Consistent with TLR4 expression, most of the $\beta$-carotene treatments led to significant decreases in the protein expression 

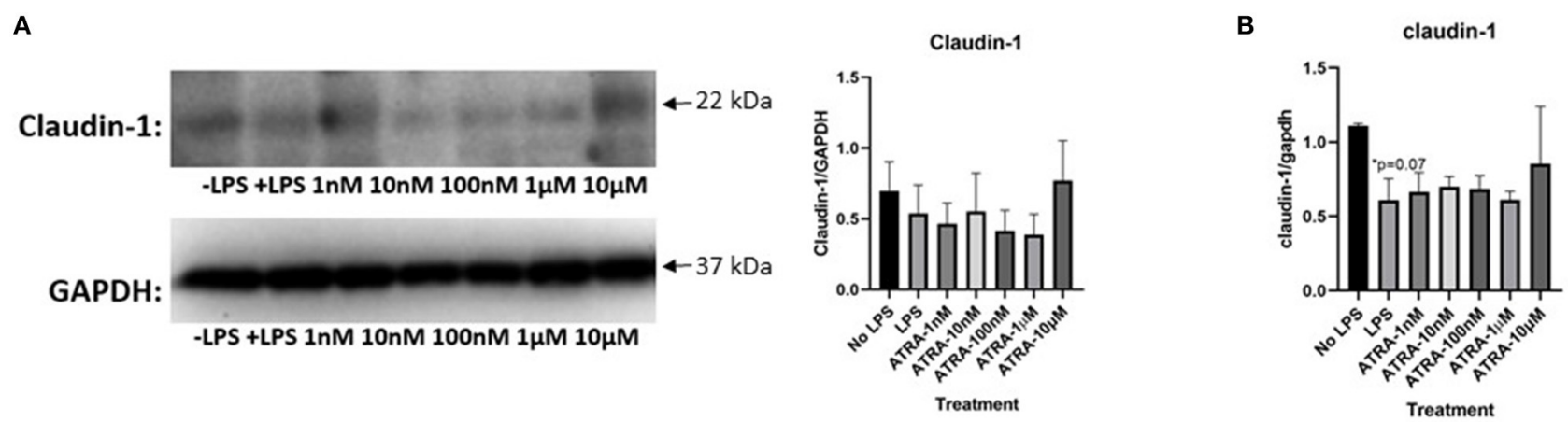

FIGURE 5 | ATRA is not as effective as in causing similar tight junction expression trends as $\beta$-carotene. (A,B) ATRA treatments on tight junction proteins or mRNA. (A) Claudin-1 WCL protein in western blot (B) and claudin-1 mRNA expressions in qPCR. Five treatment doses of ATRA (1, 10, 100 nM, 1, 10 $\mu$ M). Four replicates were used for statistical analysis in western blot and PCR. Values are means \pm SEMs. *Significance at $p<0.05$ for comparison with the "No LPS" group.

of the NF- $\kappa \mathrm{B}$ p65 subunit at concentrations of $10,100 \mathrm{nM}$, 1 , and $10 \mu \mathrm{M}$ (Figure 6C). Additionally, we investigated the nuclear translocation of NF- $\mathrm{B}$ p65 within nuclear extracts of HT-29 cells. As expected, LPS treatment significantly increased expression of NF- $\kappa \mathrm{B}$ p 65 in these nuclear extracts, and $\beta$-carotene treatments showed significant decreases seen in treatment arms $100 \mathrm{nM}$ and $1 \mu \mathrm{M}$ (Figure 6D).

We also tested whether ATRA treatments exerted similar effects in the TLR4/NF- $\mathrm{B}$ pathway. ATRA showed a slight decreasing dose-dependent trend in TLR4 expression in treated samples, albeit non-significant except at $10 \mu \mathrm{M}$ (Figure 6E). ATRA similarly affected in NF- $\mathrm{B}$ p65 expression (Figure 6F). In conclusion, $\beta$-carotene decreased LPS-induced TLR4 activation at higher treatment dosages of 1 and $10 \mu \mathrm{M}$, whereas ATRA did not. Likewise, most $\beta$-carotene treatments led to a significant decrease in the protein expression of the NF- $\kappa$ B p 65 subunit on both WCL and nuclear extracts, but ATRA had no such effect.

\section{DISCUSSION}

In the current study, $\beta$-carotene treatment in HT-29 cells reduced LPS-induced inflammation and enhanced tight junction proteins in colonic epithelial cells. In accordance, one in vivo study reported that in weaning piglets, $\beta$-carotene supplementation significantly decreased serum IL-1 $\beta$, IL-6, and TNF- $\alpha$ concentrations, compared to the cell without LPS treatment (33). Using the same animal model, the researchers found that $\beta$-carotene supplementation resulted in an attenuated jejunal permeability and improved claudin-3, occludin, and zonula occludens protein- 1 in the jejunum of piglets that have an increased risk of intestinal stress due to weaning (34). In an ulcerative colitis (UC)-associated mouse model, $\beta$-carotene supplementation at $20 \mathrm{mg} / \mathrm{kg}$ body weight (BW)/day for 28 days significantly reduced colonic IL-6 and TNF- $\alpha$ levels (35), which was in line with our findings. Another study reported that in $\beta$-lactoglobulin-sensitized mice, $\beta$-carotene at 5 and $10 \mathrm{mg} / \mathrm{kg}$ body weight significantly decreased intestinal inflammation and enhanced intestinal barrier function (36). Yu et al. reported that in rats, $\beta$-carotene supplementation suppressed LPS-induced intestinal inflammation via modulating autophagy and regulating the JAK2/STAT3 and JNK/p38 MAPK signaling pathways (37). A recent study depicted the beneficial effects of $\beta$-carotene in a DSSinduced UC model by showing decreased colonic levels of proinflammatory cytokines, lowered expression levels of phosphop65, phospho-p38 and reduced activation of Erk and JNK in the rats fed with $\beta$-carotene (38). Nevertheless, these were in vivo studies that mostly focused on small intestine, whereas we concentrated more on answering fundamental questions about the effects and potential mechanism of $\beta$-carotene treatment in modulating LPS-induced inflammation and changes in tight junction protein expression in colon, by particularly using the human epithelial cells.

The efficacy of vitamin A on intestinal barrier function was inconsistently reported. Li et al. showed that in Caco- 2 cells, ATRA treatment at $5 \mu \mathrm{M}$ substantially enhanced transepithelial electric resistance (TEER) and ZO-2 (39). On the contrary, Baltes et al. reported that ATRA treatment at $10 \mathrm{nM}-1 \mu \mathrm{M}$ in Caco2 cells significantly reduced the TEER values and increased claudin-2, a tight junction protein that decreases barrier function by forming ion pores (40). In the current study, ATRA treatment at $1 \mathrm{nM}-10 \mu \mathrm{M}$ did not show consistent effects in altering colonic inflammatory biomarkers or tight junction protein expressions. The discrepancy between our study and earlier reports might be due to the differentiation status of the cells. It is worth mentioning that plasma ATRA levels in human beings are $\sim 0.57-$ $6.6 \mathrm{ng} / \mathrm{mL}(41,42)$, at least 150 -fold less than plasma retinol concentration (41). Such value was substantially lower than the ATRA dosage given to the cells in the previous reports $(39,40)$. Therefore, future studies may be needed to achieve physiological relevance by supplementing the cells with an even lower dosage of ATRA. We failed to observe a difference of claudin-1 and occludin protein expressions in LPS-treated cells compared to the cells without LPS treatment. Multiple publications have portrayed a loss of tight junction proteins in LPS-treated cells (43-45), but none of these studies investigated the effect of LPS on tight junction protein expressions in intestinal epithelial cells. It has been reported that in mice, the injection of $2 \mathrm{mg} / \mathrm{kg}$ LPS induced resulted in gut epithelial barrier dysfunction, which was 


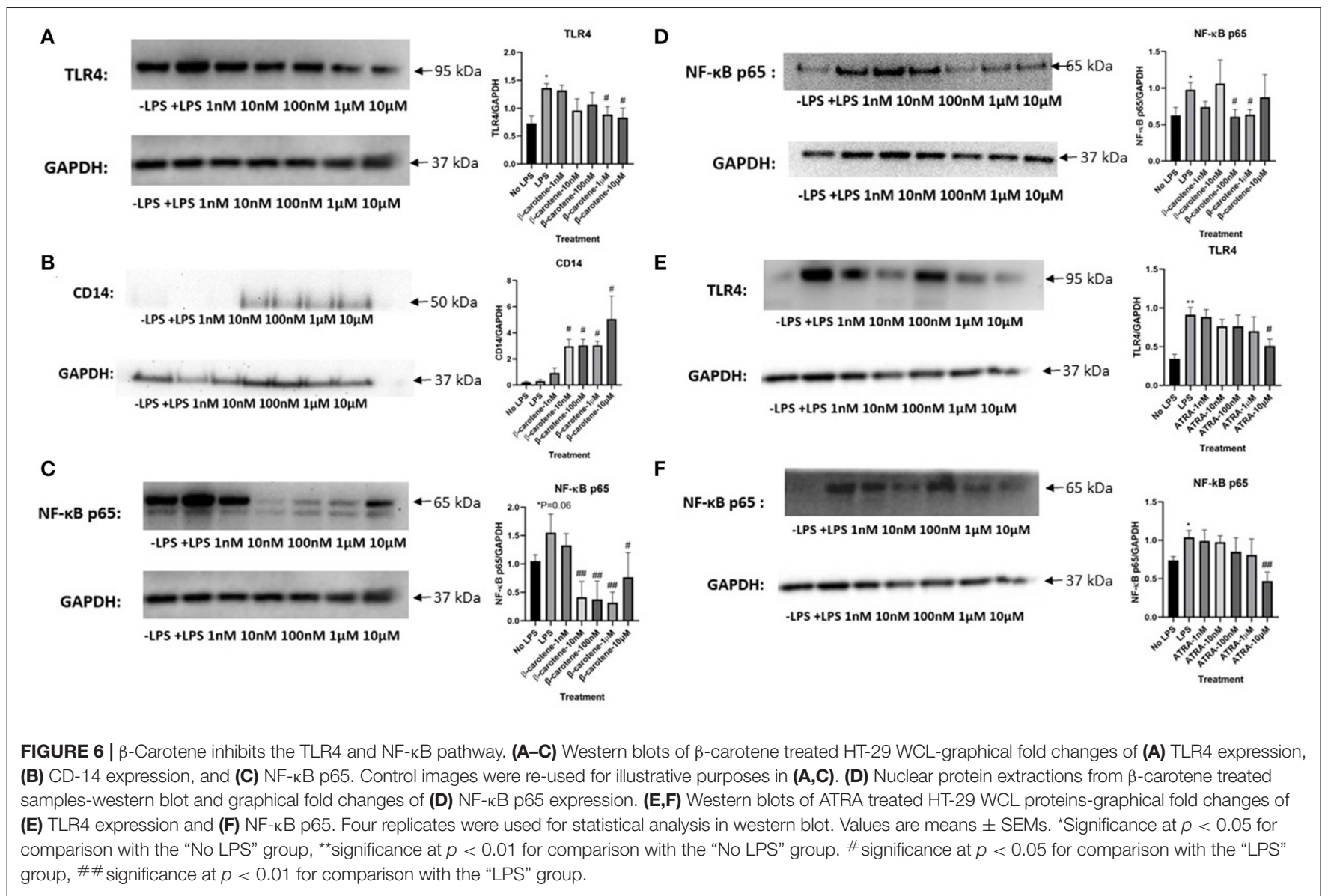

accompanied by decreased ZO-1 and occludin in the colonic mucosa (46). However, the colonic protein level of claudin-1 was comparable between the control and LPS-treatment groups (46), which was in line with our finding that LPS did not alter claudin1 protein expression. In Caco- 2 cells, LPS treatment induced an increase in tight junction permeability by up-regulating TLR4 (47). In the current study, we found that $\beta$-carotene significantly decreased TLR4 protein levels, which was associated with an enhancement of claudin-1 and occludin protein concentrations. One previous study reported that LPS increased cell permeability via an intracellular mechanism involving TLR-4-dependent regulation of CD14 (32). CD14 is a membrane protein that is constitutively expressed on the surfaces of epithelial cells (31) and showed beneficial effects against inflammatory bowel disease by mitigating inflammation and enhancing intestinal barrier function $(31,48)$. We found increased CD14 protein expression and reduced TLR4 protein expression in the cells treated with $\beta$-carotene, indicating the possibility that $\beta$-carotene might enhance claudin-1 and occludin protein levels through regulating CD14. Nevertheless, we only showed the mechanistic investigation highlighting the correlation between the TLR4CD14 pathway and tight junction expressions, not causality. We cannot rule out the possibility that $\beta$-carotene alleviated colonic inflammation and improved tight junction proteins through other molecular pathways.
Considering that HT-29 cells are hyporesponsive to LPS (49), we primed the cells with IFN- $\gamma$ at $50 \mathrm{ng} / \mathrm{mL}$ for $12 \mathrm{~h}$ before LPS treatment since priming HT-29 cells with IFN- $\gamma$ can enhance their responsiveness to LPS (49). We selected to treat the cells with LPS at a dosage of at $1 \mu \mathrm{g} / \mathrm{mL}$ for $15 \mathrm{~h}$ based on the results of our preliminary study (Supplementary Figure 1). However, it is worth mentioning that in human plasma, LPS concentration ranges from undetectable levels up to $0.2 \mathrm{ng} / \mathrm{mL}$ (50-53), even in patients with systemic endotoxemia (50), but with LPS at this range, we were not able to observe increased inflammatory cytokine release or enhanced TLR4 protein expression in HT29 cells.

Our results showed a reduction of IL- $1 \beta$ and IL- 6 in the supernatant with $\beta$-carotene treatment at any dosage, and a decrease of TNF- $\alpha$ in the cell WCL with $\beta$-carotene treatment at $10,100 \mathrm{nM}, 1$, and $10 \mu \mathrm{M}$. However, it remains unknown that whether $\beta$-carotene decreased the levels of pro-inflammatory cytokines at transcriptional levels, since we failed to detect the mRNA concentrations of these cytokines by using PCR due to their relatively low quantification in the cells.

Regarding the doses that we selected in this study, previous human studies have shown that plasma $\beta$-carotene concentration ranges from $\sim 125-425 \mathrm{nM}(54,55)$. $\beta$-Carotene concentration can be between 680 and $2,255 \mathrm{nM}$ in circulation depending on whether it is consumed as a pure compound or within the 


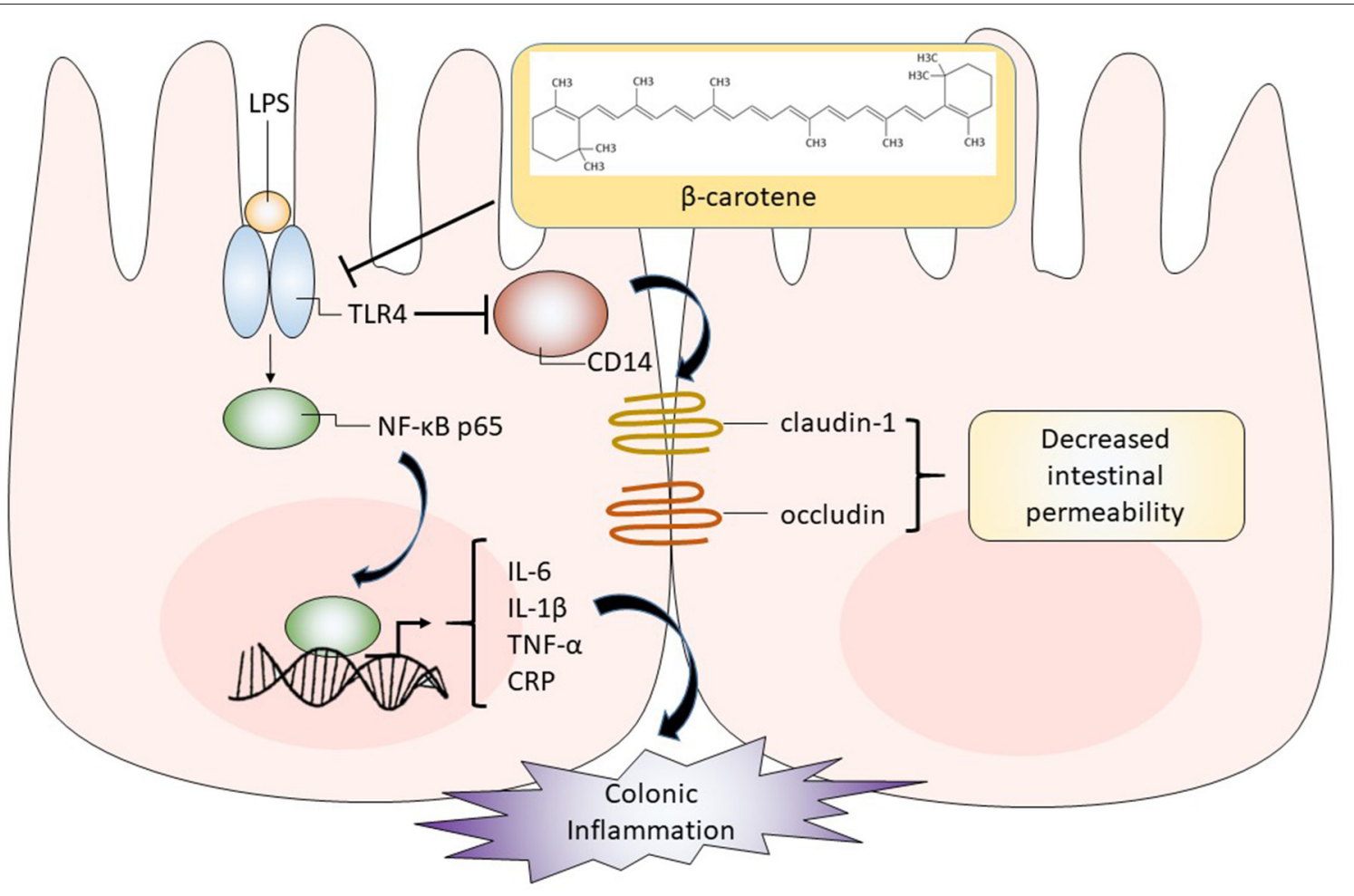

FIGURE 7 | Graphical representation of proposed pathway in which $\beta$-carotene impacts colonic epithelial cells. $\beta$-Carotene effectively inhibits the LPS-induced inflammatory response within HT-29 colonic epithelial cells by downregulating TLR4, which may block the activation and nuclear translocation of the NF- $\mathrm{B}$ p65 subunit and related downstream signaling. Thus, the release of pro-inflammatory cytokines (IL-6, IL-1 $\beta$, TNF- $\alpha$ ) is compromised. The $\beta$-carotene induced downregulation of TLR4 may also alleviate the inhibition of its co-receptor CD14. Enhanced CD14 levels by $\beta$-carotene may upregulate tight junction proteins (claudin-1 and occludin), leading to decreased intestinal permeability and enhanced barrier integrity.

foods $(54,56)$. We recently reported that engineered $S$. boulardii synthesized high doses of $\beta$-carotene in the colon of mice, and the intake of such engineered probiotics may result in an even higher $\beta$-carotene concentration in the gut (57). Altogether, the dosage of $\beta$-carotene used in this study is within physiological relevance and can be achieved by humans.

There are several limitations and shortcomings in the current study. First, we could not conduct a TEER assay to explore the LPS-induced changes in cell permeability. A differentiated HT-29 cell line is required to ensure that the cells form a monolayer to conduct TEER assay (58). However, cellular differentiation in HT-29 cells may attenuate their response to LPS by down-regulating TLR4 (59). Furthermore, the differentiated HT-29 cells may express brush-border-associated hydrolases and present brush-border microvilli, which resembles small intestinal cells (58). Since our research focuses on LPS-induced colonic dysfunction, we utilized undifferentiated HT-29 cells, which explains the inability to conduct the TEER assay. We plan to use NCM460D, a normal human colon mucosal epithelial cell line (60), to investigate further the efficacy of $\beta$-carotene in inhibiting LPS-induced colonic inflammation and colonic barrier function. Finally, yet importantly, $\beta$-carotene can be cleaved eccentrically to form a series of products such as $\beta$-apo- $14^{\prime}$-carotenoic acid and $\beta$-apo-13-carotenone (61). Since earlier reports showed that the metabolites of carotenoids from eccentric cleavage might present various beneficial effects (62-64), we cannot rule out the possibility that compared with a single $\beta$-carotene compound, the eccentric cleavage products from $\beta$-carotene may play a more prominent role in anti-inflammation and modulate tight junction proteins. Finally, we also will conduct experiments to examine whether other major dietary carotenoids would mitigate inflammation in colon.

Taken together, we provided the first evidence that $\beta$-carotene treatment, even at low dosages, can inhibit LPS-induced colonic inflammation and enhanced the expression of tight junction proteins possibly by down-regulating the TLR4 pathway as summarized in Figure 7. Further in vitro mechanistic studies and in vivo studies are warranted.

\section{DATA AVAILABILITY STATEMENT}

The original contributions generated for the study are included in the article/Supplementary Material, further inquiries can be directed to the corresponding author/s.

\section{AUTHOR CONTRIBUTIONS}

JC, EB, and AE: conceptualization, formal analysis, investigation, and supervision. JC, EB, BM, and AE: data 
curation, methodology, resources, software, validation, visualization, and writing original draft. AE: funding acquisition and project administration. All authors have read and agreed to the published version of the manuscript.

\section{FUNDING}

This work was supported by the USDA National Institute of Food and Agriculture, [Hatch] project [accession number \#1021933] and National Science Foundation Grant 1643814.

\section{REFERENCES}

1. Milani A, Basirnejad M, Shahbazi S, Bolhassani A. Carotenoids: biochemistry, pharmacology and treatment. Br J Pharmacol. (2017) 174:1290-324. doi: $10.1111 /$ bph. 13625

2. Cheng J, Eroglu A. The promising effects of astaxanthin on lung diseases. $A d v$ Nutr. (2020) 12:850-64. doi: 10.1093/advances/nmaa143

3. Yabuzaki J. Carotenoids database: structures, chemical fingerprints and distribution among organisms. Database. (2017) 2017:bax004. doi: 10.1093/database/bax004

4. Rodriguez-Concepcion M, Avalos J, Bonet ML, Boronat A, Gomez-Gomez L, Hornero-Mendez D, et al. A global perspective on carotenoids: metabolism, biotechnology, and benefits for nutrition and health. Prog Lipid Res. (2018) 70:62-93. doi: 10.1016/j.plipres.2018.04.004

5. Fernandes AS, Do Nascimento TC, Jacob-Lopes E, De Rosso VV, Zepka LQ. Carotenoids: a brief overview on its structure, biosynthesis, synthesis, and applications. In: Zepka L, Jacob-Lopes E, De Rosso VV, editors. Progress in Carotenoid Research. London: IntechOpen (2018). p. 1-15.

6. Römer S, Fraser PD. Recent advances in carotenoid biosynthesis, regulation and manipulation. Planta. (2005) 221:305-8. doi: 10.1007/s00425-005-1533-5

7. Eroglu A, Hruszkewycz DP, Curley RW Jr, Harrison EH. The eccentric cleavage product of $\beta$-carotene, $\beta$-apo-13-carotenone, functions as an antagonist of RXR $\alpha$. Arch Biochem Biophys. (2010) 504:11-16. doi: 10.1016/j.abb.2010.07.025

8. Khachik F, Spangler CJ, Smith JC Jr., Canfield LM, Steck A, et al. Identification, quantification, and relative concentrations of carotenoids and their metabolites in human milk and serum. Anal Chem. (1997) 69:1873-81. doi: $10.1021 /$ ac961085i

9. Institute of Medicine (US) Panel on Dietary Antioxidants and Related Compounds (2000). Dietary ReferenceIntakes for Vitamin C, Vitamin E, Selenium, and Carotenoids. Washington, DC: National Academies Press (US). 8, $\beta$-Carotene and Other Carotenoids. Available online at: https://www.ncbi. nlm.nih.gov/books/NBK225469/

10. Eroglu A, Harrison EH. Carotenoid metabolism in mammals, including man: formation, occurrence, and function of apocarotenoids. J Lipid Res. (2013) 54:1719-30. doi: 10.1194/jlr.R039537

11. Clark S. Beta Carotene. In: Enna SJ, Bylund DB, editors. xPharm: The Comprehensive Pharmacology Reference. New York, NY: Elsevier (2007). p. 1-3.

12. Wang XD, Krinsky NI, Marini RP, Tang G, Yu J, Hurley R, et al. Intestinal uptake and lymphatic absorption of beta-carotene in ferrets: a model for human beta-carotene metabolism. Am J Physiol. (1992) 263:G480-6. doi: 10.1152/ajpgi.1992.263.4.G480

13. Harrison EH. Mechanisms involved in the intestinal absorption of dietary vitamin A and provitamin A carotenoids. Biochim Biophys Acta. (2012) 1821:70-7. doi: 10.1016/j.bbalip.2011.06.002

14. Schultz H, Ying GS, Dunaief JL, Dunaief DM. Rising plasma beta-carotene is associated with diminishing C-reactive protein in patients consuming a dark green leafy vegetable-rich, Low Inflammatory Foods Everyday (LIFE) diet. Am J Lifestyle Med. (2019). doi: 10.1177/1559827619894954. [Epub ahead of print].

\section{ACKNOWLEDGMENTS}

The authors thank Plants for Human Health Institute at NC State University for providing excellent facilities. We also thank Drs. Arife Unal Eroglu and Changqing Zhang for their assistance in setting up our ICC protocol.

\section{SUPPLEMENTARY MATERIAL}

The Supplementary Material for this article can be found online at: https://www.frontiersin.org/articles/10.3389/fnut.2021. 723480/full\#supplementary-material

15. Crain FD, Lotspeich FJ, Krause RF. Biosynthesis of retinoic acid by intestinal enzymes of the rat. J Lipid Res. (1967) 8:249-54. doi: 10.1016/S0022-2275(20)40145-2

16. Rodríguez-Rodríguez E, López-Sobaler AM, Navia B, Andrés P, JiménezOrtega AI, Ortega RM. $\beta$-Carotene concentration and its association with inflammatory biomarkers in Spanish school children. Ann Nutr Metab. (2017) 71:80-7. doi: 10.1159/000479009

17. Atreya R, Neurath MF. Involvement of IL-6 in the pathogenesis of inflammatory bowel disease and colon cancer. Clin Rev Allergy Immunol. (2005) 28:187-96. doi: 10.1385/CRIAI:28:3:187

18. De Simone V, Franzè E, Ronchetti G, Colantoni A, Fantini MC, Di Fusco D, et al. Th17-type cytokines, IL- 6 and TNF- $\alpha$ synergistically activate STAT3 and NF-kB to promote colorectal cancer cell growth. Oncogene. (2015) 34:3493503. doi: 10.1038/onc.2014.286

19. Bai SK, Lee SJ, Na HJ, Ha KS, Han JA, Lee H, et al. beta-Carotene inhibits inflammatory gene expression in lipopolysaccharide-stimulated macrophages by suppressing redox-based NF-kappaB activation. Exp Mol Med. (2005) 37:323-34. doi: 10.1038/emm.2005.42

20. Li R, Hong $\mathrm{P}$, Zheng $\mathrm{X}$. $\beta$-carotene attenuates lipopolysaccharide-induced inflammation via inhibition of the NF- $\mathrm{B}$, JAK2/STAT3 and JNK/p38 MAPK signaling pathways in macrophages. Anim Sci J. (2019) 90:140-8. doi: $10.1111 /$ asj. 13108

21. Bertani B, Ruiz N. Function and biogenesis of lipopolysaccharides. EcoSal Plus. (2018) 8. doi: 10.1128/ecosalplus.ESP-0001-2018. [Epub ahead of print].

22. Wan J, Shan Y, Fan Y, Fan C, Chen S, Sun J, et al. NF- $\kappa$ B inhibition attenuates LPS-induced TLR4 activation in monocyte cells. Mol Med Rep. (2016) 14:4505-10. doi: 10.3892/mmr.2016.5825

23. Christian F, Smith EL, Carmody RJ. The regulation of NF- $\kappa$ B subunits by phosphorylation. Cells. (2016) 5:12. doi: 10.3390/cells5010012

24. Giuliani C, Bucci I, Napolitano G. The role of the transcription factor nuclear factor-kappa B in thyroid autoimmunity and cancer. Front Endocrinol. (2018) 9:471. doi: 10.3389/fendo.2018.00471

25. Liu T, Zhang L, Joo D, Sun SC. NF-кB signaling in inflammation. Signal Transduct Target Ther. (2017) 2:17023. doi: 10.1038/sigtrans.2017.23

26. Bhat AA, Uppada S, Achkar IW, Hashem S, Yadav SK, Shanmugakonar $\mathrm{M}$, et al. Tight junction proteins and signaling pathways in cancer and inflammation: a functional crosstalk. Front Physiol. (2018) 9:1942. doi: 10.3389/fphys.2018.01942

27. Ahmad R, Rah B, Bastola D, Dhawan P, Singh AB. Obesity-induces organ and tissue specific tight junction restructuring and barrier deregulation by claudin switching. Sci Rep. (2017) 7:5125. doi: 10.1038/s41598-017-04989-8

28. $\mathrm{Mu} \mathrm{Q}$, Kirby J, Reilly CM, Luo XM. Leaky gut as a danger signal for autoimmune diseases. Front Immunol. (2017) 8:598-598. doi: 10.3389/fimmu.2017.00598

29. Cheng J, Miller B, Balbuena E, Eroglu A. Lycopene protects against smokinginduced lung cancer by inducing base excision repair. Antioxidants. (2020) 9:643. doi: 10.3390/antiox9070643

30. Yeruva S, Ramadori G, Raddatz D. NF-kappaB-dependent synergistic regulation of CXCL10 gene expression by IL-1beta and IFN-gamma in human intestinal epithelial cell lines. Int J Colorectal Dis. (2008) 23:305-17. doi: 10.1007/s00384-007-0396-6 
31. De Buhr MF, Hedrich HJ, Westendorf AM, Obermeier F, Hofmann C, Zschemisch NH, et al. Analysis of Cd14 as a genetic modifier of experimental inflammatory bowel disease (IBD) in mice. Inflamm Bowel Dis. (2009) 15:1824-36. doi: 10.1002/ibd.21030

32. Guo S, Al-Sadi R, Said HM, Ma TY. Lipopolysaccharide causes an increase in intestinal tight junction permeability in vitro and in vivo by inducing enterocyte membrane expression and localization of TLR-4 and CD14. Am J Pathol. (2013) 182:375-87. doi: 10.1016/j.ajpath.2012.10.014

33. Li R, Li L, Hong P, Lang W, Hui J, Yang Y, et al. $\beta$-Carotene prevents weaninginduced intestinal inflammation by modulating gut microbiota in piglets. Asian Australas J Anim Sci. (2019) 34:1221-34. doi: 10.5713/ajas.19.0499

34. Wuying L, Haizhou G, Ruonan L, Min W, Qianran C, Taiping W, et al. Dietary supplementation of $\beta$-carotene on growth performance, jejunal permeability and tight junction proteins in weaned piglets. Res Square. (2020) 10:10391052.

35. Trivedi PP, Jena GB. Mechanistic insight into beta-carotene-mediated protection against ulcerative colitis-associated local and systemic damage in mice. Eur J Nutr. (2015) 54:639-52. doi: 10.1007/s00394-014-0745-5

36. Grar H, Dib W, Gourine H, Negaoui H, Taleb BHF, Louaar A, et al. $\beta$-Carotene improves intestinal barrier function by modulating proinflammatory cytokines and improving antioxidant capacity in $\beta$ lactoglobulin-sensitized mice. J Biol Regulat Homeostatic Agents. (2020) 34:1689-97. doi: 10.23812/20-24-A

37. Yang Y, Li R, Hui J, Li L, Zheng X. $\beta$-Carotene attenuates LPS-induced rat intestinal inflammation via modulating autophagy and regulating the JAK2/STAT3 and JNK/p38 MAPK signaling pathways. J Food Biochem. (2021) 45:e13544. doi: 10.1111/jfbc. 13544

38. Zhu L, Song Y, Liu H, Wu M, Gong H, Lan H, et al. Gut microbiota regulation and anti-inflammatory effect of $\beta$-carotene in dextran sulfate sodium-stimulated ulcerative colitis in rats. J Food Sci. (2021) 86:2118-30. doi: 10.1111/1750-3841.15684

39. Li Y, Gao Y, Cui T, Yang T, Liu L, Li T, et al. Retinoic acid facilitates tolllike receptor 4 expression to improve intestinal barrier function through retinoic acid receptor beta. Cell Physiol Biochem. (2017) 42:1390-406. doi: $10.1159 / 000479203$

40. Baltes S, Nau H, Lampen A. All-trans retinoic acid enhances differentiation and influences permeability of intestinal Caco-2 cells under serum-free conditions. Dev Growth Differ. (2004) 46:503-14. doi: 10.1111/j.1440-169x.2004.00765.x

41. Napoli JL, Pramanik BC, Williams JB, Dawson MI, Hobbs PD. Quantification of retinoic acid by gas-liquid chromatography-mass spectrometry: total versus all-trans-retinoic acid in human plasma. J Lipid Res. (1985) 26:387-92. doi: 10.1016/S0022-2275(20)34382-0

42. Morgenstern J, Fleming T, Kliemank E, Brune M, Nawroth P, Fischer A. Quantification of all-trans retinoic acid by liquid chromatography-tandem mass spectrometry and association with lipid profile in patients with type 2 diabetes. Metabolites. (2021) 11:60. doi: 10.3390/metabo11010060

43. Sheth P, Delos Santos N, Seth A, Larusso NF, Rao RK. Lipopolysaccharide disrupts tight junctions in cholangiocyte monolayers by a c-Src-, TLR4-, LBP-dependent mechanism. Am J Physiol Gastrointest Liver Physiol. (2007) 293:G308-18. doi: 10.1152/ajpgi.00582.2006

44. Fujita T, Firth JD, Kittaka M, Ekuni D, Kurihara H, Putnins EE. Loss of claudin-1 in lipopolysaccharide-treated periodontal epithelium. J Periodontal Res. (2012) 47:222-7. doi: 10.1111/j.1600-0765.2011.0 1424.x

45. Kobayashi K, Oyama S, Numata A, Rahman MM, Kumura H. Lipopolysaccharide disrupts the milk-blood barrier by modulating claudins in mammary alveolar tight junctions. PLOS ONE. (2013) 8:e62187. doi: 10.1371/journal.pone.00 62187

46. Han X, Fink MP, Yang R, Delude RL. Increased iNOS activity is essential for intestinal epithelial tight junction dysfunction in endotoxemic mice. Shock. (2004) 21:261-70. doi: 10.1097/01.shk.0000112346.38599.10

47. Guo S, Nighot M, Al-Sadi R, Alhmoud T, Nighot $\mathrm{P}$, Ma TY. Lipopolysaccharide regulation of intestinal tight junction permeability is mediated by tlr4 signal transduction pathway activation of FAK and MyD88. J Immunol. (2015) 195:4999-5010. doi: 10.4049/jimmunol.14 02598
48. Buchheister S, Buettner M, Basic M, Noack A, Breves G, Buchen B, et al. CD14 Plays a protective role in experimental inflammatory bowel disease by enhancing intestinal barrier function. Am J Pathol. (2017) 187:1106-20. doi: 10.1016/j.ajpath.2017.01.012

49. Suzuki M, Hisamatsu T, Podolsky DK. Gamma interferon augments the intracellular pathway for lipopolysaccharide (LPS) recognition in human intestinal epithelial cells through coordinated up-regulation of LPS uptake and expression of the intracellular Toll-like receptor 4-MD-2 complex. Infect Immun. (2003) 71:3503-11. doi: 10.1128/IAI.71.6.3503-3511. 2003

50. Wellmann W, Fink PC, Benner F, Schmidt FW. Endotoxaemia in active Crohn's disease. Treatment with whole gut irrigation and 5-aminosalicylic acid. Gut. (1986) 27:814-20. doi: 10.1136/gut.27. 7.814

51. Gardiner KR, Halliday MI, Barclay GR, Milne L, Brown D, Stephens S, et al. Significance of systemic endotoxaemia in inflammatory bowel disease. Gut. (1995) 36:897-901. doi: 10.1136/gut.36.6.897

52. Hurley JC. Endotoxemia: methods of detection and clinical correlates. Clin Microbiol Rev. (1995) 8:268-92. doi: 10.1128/CMR.8. 2.268

53. Andreasen AS, Krabbe KS, Krogh-Madsen R, Taudorf S, Pedersen BK, Møller K. Human endotoxemia as a model of systemic inflammation. Curr Med Chem. (2008) 15:1697-705. doi: 10.2174/0929867087848 72393

54. Mayne ST, Cartmel B, Silva F, Kim CS, Fallon BG, Briskin K, et al. Effect of supplemental beta-carotene on plasma concentrations of carotenoids, retinol, and alpha-tocopherol in humans. Am J Clin Nutr. (1998) 68:642-7. doi: $10.1093 /$ ajcn/68.3.642

55. Wallström P, Wirfält E, Lahmann PH, Gullberg B, Janzon L, Berglund G. Serum concentrations of beta-carotene and alpha-tocopherol are associated with diet, smoking, and general and central adiposity. Am J Clin Nutr. (2001) 73:777-85. doi: 10.1093/ajen/73.4.777

56. Novotny JA, Kurilich AC, Britz SJ, Clevidence BA. Plasma appearance of labeled beta-carotene, lutein, and retinol in humans after consumption of isotopically labeled kale. J Lipid Res. (2005) 46:1896-903. doi: 10.1194/jlr.M400504-JLR200

57. Durmusoglu D, Al'abri IS, Collins SP, Cheng J, Eroglu A, Beisel CL, et al. In situ biomanufacturing of small molecules in the mammalian gut by probiotic Saccharomyces boulardii. ACS Synth Biol. (2021) 10:1039-52. doi: 10.1021/acssynbio.0c0 0562

58. Verhoeckx K, Cotter P, López-Expósito I, Kleiveland C, Lea T, Mackie A, et al., editors. HT29 cell line. In: The Impact of Food Bioactives on Health: in vitro and ex vivo Models [Internet]. Cham: Springer (2015). doi: 10.1007/978-3-319-16104-4

59. Lee SK, Il Kim T, Kim YK, Choi CH, Yang KM, Chae B, et al. Cellular differentiation-induced attenuation of LPS response in HT-29 cells is related to the down-regulation of TLR4 expression. Biochem Biophys Res Commun. (2005) 337:457-63. doi: 10.1016/j.bbrc.2005. 09.071

60. Moyer MP, Manzano LA, Merriman RL, Stauffer JS, Tanzer LR. NCM460, a normal human colon mucosal epithelial cell line. In Vitro Cell Dev Biol Anim. (1996) 32:315-7. doi: 10.1007/BF02722955

61. Eroglu A, Hruszkewycz DP, Dela Sena C, Narayanasamy S, Riedl $\mathrm{KM}$, Kopec RE, et al. Naturally occurring eccentric cleavage products of provitamin A $\beta$-carotene function as antagonists of retinoic acid receptors. J Biol Chem. (2012) 287:15886-95. doi: 10.1074/jbc.M111. 325142

62. Ip BC, Hu KQ, Liu C, Smith DE, Obin MS, Ausman LM, et al. Lycopene metabolite, apo-10'-lycopenoic acid, inhibits diethylnitrosamineinitiated, high fat diet-promoted hepatic inflammation and tumorigenesis in mice. Cancer Prev Res. (2013) 6:1304-16. doi: 10.1158/1940-6207.CAPR-1 3-0178

63. Cheng J, Miao B, $\mathrm{Hu}$ KQ, Fu X, Wang XD. Apo-10'lycopenoic acid inhibits cancer cell migration and angiogenesis and induces peroxisome proliferator-activated receptor $\gamma . J$ Nutr Biochem. (2018) 56:26-34. doi: 10.1016/j.jnutbio.2018. 01.003 
64. Balbuena E, Cheng J, Eroglu A. The role of lycopene in chronic lung diseases. In: Shalaby E, editor. Antioxidants. London, UK: IntechOpen (2021).

Conflict of Interest: The authors declare that the research was conducted in the absence of any commercial or financial relationships that could be construed as a potential conflict of interest.

Publisher's Note: All claims expressed in this article are solely those of the authors and do not necessarily represent those of their affiliated organizations, or those of the publisher, the editors and the reviewers. Any product that may be evaluated in this article, or claim that may be made by its manufacturer, is not guaranteed or endorsed by the publisher.

Copyright $\odot 2021$ Cheng, Balbuena, Miller and Eroglu. This is an open-access article distributed under the terms of the Creative Commons Attribution License (CC BY). The use, distribution or reproduction in other forums is permitted, provided the original author(s) and the copyright owner(s) are credited and that the original publication in this journal is cited, in accordance with accepted academic practice. No use, distribution or reproduction is permitted which does not comply with these terms. 